\title{
Turkey's foreign policy activism: vision continuity and reality checks
}

\author{
loannis N. Grigoriadis
}

To cite this article: loannis N. Grigoriadis (2014) Turkey's foreign policy activism: vision continuity and reality checks, Southeast European and Black Sea Studies, 14:2, 159-173, DOI: 10.1080/14683857.2014.903599

To link to this article: http://dx.doi.org/10.1080/14683857.2014.903599

曲 Published online: 02 May 2014.

Submit your article to this journal

Џlll Article views: 774

Q View related articles $\sqsubset$

View Crossmark data \lceil

7 Citing articles: 1 View citing articles 


\title{
Turkey's foreign policy activism: vision continuity and reality checks $^{\star}$
}

\author{
Ioannis N. Grigoriadis* \\ Department of Political Science \& Public Administration, Bilkent University, Bilkent \\ University, Room T-364, Bilkent, Ankara TR-06800, Turkey
}

(Received 29 May 2013; accepted 23 December 2013)

\begin{abstract}
It is argued in this study that Turkey's ambition to play a key regional role and become a global actor is not novel. There have been at least two similar initiatives in recent history which defended Turkey's extraordinary strategic potential and aspired to put it into the heart of global politics. What has, however, been indeed novel and has lent credibility to the whole experiment is Turkey's recent economic dynamism and political reforms. While such a trend is indeed reasonable, Turkey's claims for a global strategic role and a value-based foreign policy may be already overblown. Turkey is bound to play a key regional role and may indeed become a global actor in the years to come; its capabilities, however, are not infinite, and significant risks may lurk in their overestimation.
\end{abstract}

Keywords: Turkey; foreign policy; political economy; soft power; democratization; Middle East

\section{Introduction}

The recent growing interest in Turkish foreign policy can be attributed to several reasons. The rise of key states of the global South into political prominence has affected the position of Turkey. Global politics in the aftermath of the 11 September attacks have also raised attention to the role of Turkey as a link between the West and the Islamic world and a potential role model for other Muslim countries. This debate became even more relevant given the Islamist origins of Turkey's incumbent Justice and Development Party (Adalet ve Kalkınma Partisi-AKP). The advent of the AKP administration in 2002 was linked with a set of comprehensive changes in Turkish politics and society. In the field of foreign policy, Turkey's political reform drive led to the start of EU accession negotiations in October 2005. While EU accession negotiations lost traction in the following years, Turkey developed close relations with most of its Middle Eastern neighbours. The rise of Ahmet Davutoğlu to the post of Foreign Minister in May 2009 attracted even more attention to Turkish foreign policy. Being an academic who had outlined a strategic vision about Turkey before entering the political arena and having already exerted considerable influence on foreign policy as chief advisor to Prime Minister Recep Tayyip Erdoğan, Davutoğlu emerged

\footnotetext{
*Email: ioannis@bilkent.edu.tr

*An earlier version of this article was awarded an honorable mention at the 2011 Sakip Sabanc1 International Research Award competition. 
as a key actor in the reconfiguration of Turkish foreign policy (Abramowitz and Barkey 2009; Aras 2009a, 127-9). His vision, often dubbed as the 'Davutoğlu Doctrine', aimed to position Turkey into the heart of global and regional politics and turn it into a pivotal player. This study argues is that the foreign policy vision of the AKP can be better understood if examined in the context of two previous foreign policy visions advanced by Turgut Özal and Ismail Cem. What has been novel though in the AKP years is the robustness of Turkish economy, as well as substantial political reform between 1999 and 2005. Both have underwritten Turkey's ambitions to play a key regional and global role but also pose a set of limitations. Turkey's foreign policy capabilities are not unlimited, as post-2011 developments in the Middle East have underlined. The sustainability of Turkey's growing international role is contingent upon a set of strategic choices which could help consolidate the country's economic and political achievements.

\section{Three visions of foreign policy activism}

It would be inaccurate to argue that Davutoğlu's foreign policy vision has been unique in its emphasis on Turkey's rising regional and global role and its multilateral and assertive approach. Such views were in harmony with visions expressed by other Turkish politicians in recent history (Altunışık 2009, 178-85). Turgut Özal was the first to argue in the late 1980s that Turkey should follow a more assertive foreign policy and claim a leading role in regional and global affairs. In particular, he stressed that Turkey should benefit from the global strategic realignments following the end of the Cold War and the collapse of the Soviet Union, and reinforce its role in the geographic space once occupied by the Ottoman Empire. Özal reactivated Turkey's accession process to the European Economic Community (EEC) by formally applying for membership in 1987. Turkey's EEC membership bid had remained frozen since the interruption of accession negotiations in 1978 and the 1980 military coup. Özal also came to the point of publishing a book 'La Turquie en Europe', aiming to substantiate Turkey's European identity (Özal 1988). While this attempt met with limited success, his vision soon expanded well beyond the borders of the EEC. In what was confusingly - dubbed as 'neo-Ottomanism', 1 Turkey should spearhead an initiative to build and lead a 'community' of the states which succeeded the Ottoman Empire. Özal's visions extended even further and envisioned a Turkey claiming a leadership role in the vast space between the Adriatic Sea and the Chinese Wall. While such grandiose plans met with the condescension of many of Turkey's allies at the time, they soon faced the hard test of reality. In the early 1990s, Turkey entered one of the bloodiest faces of the Kurdish Workers' Party (Partiya Karkaren Kurdistan-PKK) insurgency in the east and the southeast of the country, exacting a heavy toll in human lives and damaging its international status. A major economic crisis in 1994 also underscored the incomplete transformation of Turkish economy from a state-led, inward-looking to a private sector-led export-oriented model. The fate of these ambitious plans fell short, as it became clear that Turkey did not have the infrastructure necessary to put forward such an ambitious agenda. Even in regions where high hopes were bestowed such in Central Asia and the Caucasus, Turkey's ambitions soon proved overstretched. The demise of the Soviet Union and the emergence of the postSoviet Turkic republics in Central Asia and the Caucasus did not mean that these would be willing to recognize Turkey an intermediary role between them and the 
West, let alone a suzerain. In the end, Turkey developed close economic relations with these states, yet there was no strategic relationship, or leadership of Turkey.

About 10 years later, a similar agenda was advocated by a leading political figure of Turkey's secularist Republican People's Party (Cumhuriyet Halk Partisi). Ismail Cem, Turkey's Foreign Minister at the time outlined a strategic vision with striking similarities with that of Davutoğlu. In the preface of a book on Turkey's global ambitions, Cem argued that

It is worthwhile to note that there are twenty-six states with which we shared for centuries a common history, a common state and a common fate ... In this vast socio-political geography, Turkey ... has optimal conditions to contribute to stability and to enjoy the opportunities presented by the new 'Eurasian Order.' By virtue of its historical and cultural attributes and its privileged double-identity, European, as well as Asian, Turkey is firmly positioned to become the strategic 'Center' of Eurasia. (Cem 1998)

Cem's views were also expressed on official occasions. In a speech at the United Nations General Assembly in September 1997, Cem identified five main assets to support Turkey's foreign policy objectives as follows:

(1) Historical asset and its revaluation; the modern crossroads of the East and the West.

(2) Cultural identity, the privilege of being a European nation, as well as an Asian nation.

(3) A thriving economy, great potentials of industry, trade and tourism.

(4) Proven parameters of stability and peace in a huge and most disturbed geographic region, which holds the major energy resources of the world, as well as enormous economic prospects.

(5) 'The Turkish Model', the main, if not the only experience in the world of a country with Islamic traditions, which has adopted pluralist, democratic, institutions, human rights, secular laws, gender equality (Cem 2001, 57, 2005).

The third vision of Turkish foreign policy activism has been identified with Ahmet Davutoğlu. Before he entered politics, Davutoğlu had early outlined his vision for Turkey's strategic mission and foreign policy in his book 'Strategic Depth' (Stratejik Derinlik) and other publications (Davutoğlu 2001). According to his view, Turkey, due to its history and cultural heritage, belongs to the privileged group of states which can be classified as 'central powers' and possess 'strategic depth'. Turkey should not be content with a regional role in the Balkans, the Caucasus or the Middle East, because it is not a 'regional' but a 'central power'. In Davutoğlu's view, Turkey is simultaneously a Middle Eastern, Balkan, Caucasian, Central Asian, Caspian, Mediterranean, Gulf and Black Sea country. It can exert influence in all these regions and is thus eligible to claim a global strategic role. In view of these, he objects to viewing Turkey as a bridge between East and West (Aras and Gorener 2010, 85-6), as this would relegate Turkey to a mere tool for the promotion of the strategic interests of other actors. Instead of letting other countries instrumentalize Turkey for the promotion of their own regional and global strategic role, Turkey needs to develop a proactive policy commensurate to its historic and geographic significance, which is underwritten by its Ottoman legacy (Grigoriadis 2010a, 4-5). In Davutoğlu's own words: 
... Turkey enjoys multiple regional identities and thus has the capability as well as the responsibility to follow an integrated and multidimensional foreign policy. The unique combination of our history and geography brings with it a sense of responsibility. To contribute actively towards conflict resolution and international peace and security in all these areas is a call of duty arising from the depths of a multidimensional history for Turkey. (Davutoğlu 2009, 12)

Consequently, it need no more be an instrument of Western and US regional strategies and policies. Turkey had to develop its own strategic agenda and priorities, which would not need to be coordinated with these of the United States or Europe. Davutoğlu's aims were high. In a speech towards Turkish high-level diplomats, Davutoğlu stressed that by 2023, the centenary of the Republic of Turkey, Turkey should be one of the 10 leading states in the world. He encapsulated this as follows:

By 2023 when the country will commemorate the 100th anniversary of the foundation of the republic, I envision a Turkey which is a full member of the EU after having completed all the necessary requirements, living in full peace with its neighbours, integrated with neighbouring basins in economic terms and for a common security vision, an effective player in setting orders in regions where our national interests lie, and active in all global affairs and among the top ten economies in the world. (Bozkurt 2010)

In other words, Davutoğlu's vision amounted to the full realization of Turkey's strategic and economic potential. While Turkey was already a member of the G-20 group having the seventeenth largest economy among the group members, Davutoğlu aspired to create the conditions to bring Turkey to the top 10 list.

These show that the core of Davutoğlu's views had been in fact shared by influential political actors across the Turkish political spectrum long before the rise of the AKP into power. Hence, it was not the rise of Turkish political Islam that introduced and lent credibility to culturalist and geopolitical arguments about Turkey's regional and global role. In fact, such views found resonance even among key policy analysts in the West who acknowledged a 'pivotal role' for Turkey in the postCold War Eurasian strategic environment (Brzezinski 1997). Yet, conditions were not yet mature for the flourishing of this foreign policy vision. The 1999-2001 economic crisis which brought Turkey to the brink of economic collapse humbled once again Turkish ambitions. It highlighted that no multidimensional foreign policy could be founded on fragile economic foundations. It was the congruence of a set of favourable domestic and international conditions which emerged following the rise of the AKP to power in 2002 that allowed for the stronger articulation of these views. What was really different in Davutoğlu's foreign policy thesis was his attempt to project Turkey's image as a 'soft power' and promote the resolution of domestic and bilateral conflicts due to their obstructive role to Turkey's transformation into a global actor. Yet, the support which Davutoğlu's vision enjoyed across the political spectrum points at a wider political consensus. Firmly based on Turkish nationalism, his ambitious agenda has been in harmony with mainstream views of bureaucrats, officers and irrespective of their position on the question of secularism. Davutoğlu also announced his intention to ask for a sharp rise of the budget and the personnel of the Turkish Foreign Ministry, so it could stand up to the new role he envisioned for Turkey (Bozkurt 2010). The rising role, budget and size of the Turkish diplomatic service has been a trend welcome by secular Turkish 
diplomatic elite and formed an additional ground for mutual understanding and enhanced cooperation.

\section{From vision to reality: Turkey's changing economic and political fortunes}

While Turkey's foreign policy activism has been an element of continuity in foreign policy visions of the last decades, it appeared to fit better the circumstances following the rise of the AKP to power in 2002. Turkey's rising regional and global role also can be viewed within a process of global strategic reconfiguration rooted in economy. The rise of the so-called BRIC states into economic prominence is considered to be one of the most critical and lasting shifts of the beginning of the new century and is meant to entail major political and strategic ramifications. Alongside China, India, Russia and Brazil, a group of 'second-tier BRICs', consists of smaller but equally dynamic states, such as Mexico, South Africa, South Korea, Indonesia and Turkey. Being a member of this group, Turkey can claim a bigger role on a regional and potentially on a global basis. Its buoyant economy remains the touchstone of this development and a permissive condition for its sustainability.

While Turkey faced in 1999-2001 one of the most acute economic crises in its republican history, it has been able to become one of the most spectacular economic success stories by the end of the same decade. Following the transformation of Turkish economy in the 1980s, Turkish economy escaped from the grip of statism, yet it was not able to escape from a vicious circle of chronic problems. Hyperinflation, large public debt and chronic current account deficits compounded by corruption and an incompetent state administration undermined the stability of Turkish economy. Economic crises had acquired cyclical proportions until the fateful 2001. Then, a row between President Sezer and Prime Minister Ecevit precipitated a collapse of the Turkish Lira/US dollar exchange rate and a crash in the Istanbul stock exchange. Within a few days, the Turkish Lira lost $35 \%$ of its value, and approximately one million jobs were lost. An austere stabilization programme was urgently introduced under the auspices of the International Monetary Fund.

In the elections of November 2002, the Turkish people punished the political parties responsible for this economic calamity. None of the government coalition partners succeeded in crossing the $10 \%$ threshold and lost their parliamentary representation. The AKP formed a strong single-party government after many years in Turkey, yet it faced a serious legitimacy challenge, due to its questionable Kemalist credentials and Islamist roots. Nonetheless, the AKP government convinced key private economic actors, such as the Association of Turkish Industrialists and Businesspersons (Türk Sanayicileri ve İşadamları Derneği-TÜSİAD) that it would comprise a responsible steward of Turkish economy and promote the cause of Turkey's democratic consolidation through the EU reform process. The dramatic improvement of EU-Turkey relations and the 2004 decision of the European Council to start accession negotiations with Turkey only added to economic optimism, as it secured a critical political anchor. The combination of a successful economic austerity and privatization programme with a daring democratization package yielded unprecedented results. Turkey's GDP grew by an average annual rate of $6.8 \%$ between 2001 and 2007. GDP growth fell to $0.7 \%$ in 2008. At the heyday of the global economic crisis, GDP contracted by $4.7 \%$ in 2009 , only to sharply recover in 2010. Inflation which used to reach three-digit figures in the not-so-distant past fell below the $10 \%$ threshold. The Turkish lira which used to be one of the least 
trusted and most volatile currencies eventually became a currency of choice for financial investors. Foreign Direct Investment (FDI) reached record levels. While between 1990 and 2004 average FDI inflows amounted to 1 billion USD, FDI rose $240 \%$ in $2004-2005$ and $105 \%$ in 2005-2006. In 2006, 20.2 billion USD was invested in Turkey, the highest ever in republican Turkey's history (Grigoriadis and Kamaras 2008, 64). The Istanbul stock exchange has been among the best performing ones on a global level. Trade volume rose from 72.4 billion USD in 2002 to 334 billion USD in 2008 and in 2010. In particular, Turkey's trade to the Middle East and North Africa region grew from $8.51 \%$ in 2003 to $12.9 \%$ in the first months of 2010. Trade to Asian countries rose from $18.79 \%$ in 2003 to 29.3 in 2010. While the European Union remained the key commercial partner of Turkey, the weighting of the trade with EU member states as a percentage of the overall trade fell significantly from $53.63 \%$ in 2003 to $41.6 \%$ in 2010 (Öniş 2011, 56).

The dynamism of Turkish economy discounted the fears expressed in the aftermath of the 1995 Customs Union between the European Union and Turkey about the loss of Turkish domestic market to European competitors. On the contrary, Turkish economy was robust enough to benefit from trade liberalization and increase its exports to the European Union. ${ }^{2}$ Turkish economic growth projected the profile of a successful state which was able to make steps towards democratization while achieving key development targets. In a nutshell, lessons learnt from the recurrent economic crises of the past allowed Turkey to navigate through the global economic crisis with remarkable success. While other Western economies came to suffer from fiscal profligacy and insufficient regulation of the banking sector, Turkey had already seen the worst and developed safeguarding mechanisms.

Turkish economic dynamism has had a catalytic effect on the country's international image and contributed to the reformulation of its foreign policy. Economic diplomacy has become one of the key pillars of Turkish foreign policy planning. Turkey's growing interest in hitherto neglected regions of the globe, such as subSaharan Africa and Latin America was meant to support growing economic relations of Turkish entrepreneurs and translate these into stronger political relations. Turkish entrepreneurship has grown into regions which until recently remained beyond reach. Sub-Saharan Africa and Latin America attracted unprecedented attention by Turkish diplomatic authorities. A 'Turkey-Africa Cooperation Summit' with the participation of 49 African countries took place in Istanbul between 18 and 21 August 2008. Following that key meeting, a series of Turkey-Africa summits were organized in Turkey with the participation of numerous African leaders. In a speech Davutoğlu delivered in January 2010, he stated that seven new embassies were opened in 2009, while 26 would open in 2010 most of which in sub-Saharan Africa and Latin America (Bozkurt 2010). It was planned that the overall number of Turkish embassies in Africa would rise to 30 from 12 in 2008 (Özkan 2011, 101). This decision is reflective of a mutually reinforcing trend of increasing political and economic activism. In many cases, the expansion of Turkish foreign policy in distant parts of the world has been following rather than leading Turkish entrepreneurship. Hence, one could argue that Turkish foreign policy has been to a certain extent privatized (Atl 12011, 117-21). In a nutshell, Turkey has emerged as a new 'trading state', capitalizing on its extrovert and entrepreneurial economy to improve its regional and global influence (Kirişçi 2009, 38-41; Rosecrance 1986, 27).

Political reform also contributed to the changing fortunes of Turkish foreign policy. Between 1999 and 2005 Turkey underwent a political reform process which 
could only be compared with the Ataturk reforms of the late 1920s and early 1930s. Both the 1999-2002 coalition government and the AKP single-party government between 2002 and 2005 worked hard to promote the standard of political freedoms and human rights. Nine reform packages amended the constitutional and legislative framework to put forward a comprehensive democratization programme aiming to meet the Copenhagen Criteria for EU membership (Özbudun 2007, 110). Institutions which embodied the tutelary role of the military in Turkish politics and the limited character of Turkish democracy, such as the state security courts (Devlet Güvenlik Mahkemeleri) were abolished, while other, such as the National Security Council (Milli Güvenlik Kurulu-MGK) were reformed, so they came under firm civilian control. The majority of the membership of the MGK became civilian, while a civilian was elected for the first time its Secretary General. According to the amended Article 118§3:

The National Security Council shall submit to the Council of the Ministers its views on the advisory decisions that are taken and ensuring the necessary condition with regard to the formulation, establishment, and implementation of the national security policy of the state. The Council of Ministers shall evaluate decisions of the National Security Council concerning the measures that it deems necessary for the preservation of the existence and independence of the state, the integrity and indivisibility of the country and the peace and security of society. (Turkish Grand National Assembly 2011)

The term 'evaluate' replaced the term 'give priority consideration' in a clear attempt to reduce the MGK to a status purely advisory to the government. In addition, references to gender equality were reinforced, while the path towards recognizing affirmative action was also set. The constitutional protection of political and social rights improved, while the death penalty was abolished. The legal framework of civil society became more liberal and permissive to private initiative, while a more liberal balance was sought regarding Turkey's key question of state-religion relations. A compromise solution for the Kurdish issue was sought and was linked with a more inclusive definition of Turkish national identity. This was hoped to bring an end to a decade-long secessionist struggle by the PKK and give equal citizenship rights to Turkey's Kurdish minority. The overall state of minority rights improved, and long-standing discrimination against Alevis and non-Muslims seemed to dissipate for the first time in decades. Despite its authoritarian past and domestic divides along ethnic and religious lines, Turkey appeared to make critical steps towards consolidating its democracy. This led to increased interest from its neighbours, especially in the Middle East. While US hopes to promote democracy in the Middle East through military intervention in Iraq proved chimerical, Turkey was recording considerable success which was linked to the positive impact of EU membership conditionality. Turkey's prospective EU membership appeared to be both an anchor of Turkey's economic and as well as a trigger for the completion of the democratic consolidation process.

These have contributed to a significant change in Turkey's international image. Turkey was no more perceived as a militaristic, secularist, pro-Western, bastion of the West in its struggles against the Soviet bloc or Islamic fundamentalism. It was viewed as a Muslim-majority state, which has been able to strike a fine balance between its Islamic identity and its Western political and economic orientation. The appeal of Turkey very strongly depended on its Western links, democratic regime 
as well as the success of its economy. The country with the second biggest standing army in NATO was now seen as a regional soft power and a role model. Under Foreign Minister Davutoğlu, a 'zero problem policy with neighbors' was launched, aspiring to rid Turkey of long-standing regional disputes and unlock its regional strategic potential. Turkish makes and brands started gaining regional and global recognition, while Turkish media and entertainment industry made big inroads into regional markets and claimed a major role in shaping popular culture. The Turkish TV and cinema industry had Turkish media and movies have found new audience and met with remarkable success in the Middle East. Pre-existing cultural affinities were matched by admiration for the Turkish economic and political system. Turkey was no longer seen as the heir of an 'oppressive, rapacious empire' - as Arab nationalism has depicted the Ottoman Empire - but as a role model (Altunışı 2008; Kalın 2011).

\section{Activism practiced: lessons from the pre-2011 Middle East}

Turkey's diplomatic engagement in the Middle East before the outbreak of the 'Arab Spring' has been widely documented and explored and linked with numerous diplomatic initiatives in the region. Turkey has attempted to mediate and promote conflict resolution in Lebanon, Iraq and Sudan and launched initiatives aiming to improve its own relations with Armenia, Syria and the Kurdistan Regional Government (KRG) of Iraq. This has attracted considerable praise, in particular in the Middle East, where Turkey was perceived by the public opinion to be an honest broker and power of economic and political change (Aras 2009b; Aras and Karakaya Polat 2007). Improvement of bilateral diplomatic and economic relations has been complemented by the development of regional integration schemes. The signature of bilateral agreements with Syria, Libya, Yemen, Lebanon and Jordan regarding the lifting of visa requirement for tourist visits was followed by the establishment of 'Strategic Cooperation Councils' with Syria and Iraq (Devrim and Soler i Lecha 2010). As a corollary to these, a project promoting the economic integration of Turkey, Syria, Lebanon and Jordan following the European example was put forward through consecutive multilateral minister meetings (Istanbul Office 2010). In March 2011, Turkish officials floated the idea of 'Shamgen', a treaty similar to the European Schengen Treaty, which would introduce a regional visa scheme for Turkey, Iran, Iraq and Syria - with potential expansion to Yemen, Lebanon, Libya, Morocco and Tunisia - and boost regional economic cooperation and tourism (Hammed 2011).

Alongside the improvement of bilateral relations, Turkey's growing involvement in the key Middle Eastern conflicts has also led to higher visibility and popularity for the country and Prime Minister Erdoğan throughout the region. Turkey no longer appeared to be a Western agent, but a emerging moral power basing its foreign policy on values and not interests. Prime Minister Erdoğan emphasized the normative base of Turkish foreign policy as follows:

The global crisis, which continues today very harshly, as we have stressed in every platform, is the result of the ambitious, unsatisfied and greedy feelings to gain more ... We implied that if the system goes in that manner, this will cause much bigger crises in the future and we awakened. On the contrary, it is a serious threat for our future when the sense of justice between the states, societies and communities weakens too. This sense of justice will be eroded, if you make a clear distinction between 
terrorism and terrorist organizations. If you make clear-cut division on the nuclear weapons issue warning some countries and taking no notice of other countries, the sense of justice is going to decline. If you see in one part of the world child assassination as defence, while on the other hand, you arrange campaigns for extinct animals that cost billions of dollars, this also means that the corruption of the feeling of fellowship. The communities that perceive themselves as the crushed, worn, propelled, victimized, and downtrodden, and the communities that have no belief in justice and sincerity, make it impossible to establish peace and stability on a global scale. This is what we have emphasized in our foreign policy. We defend justice, peace, law, and democracy in every area. We, as a conservative and democratic party, are struggling to hold both real and normative policy together. (Erdoğan 2010)

In that speech, Prime Minister Erdoğan also alluded to popular arguments throughout the Middle East regarding the Palestinian question and Iran's nuclear programme: it would be, namely, unfair to demand that Iran freeze its nuclear programme, while Israel has not been sanctioned for its violation of nuclear proliferation treaties and development of nuclear weapons. Claiming a moral basis for Turkey's foreign policy found strong resonance in Arab public opinion. The popularity of Prime Minister Erdoğan reached high peaks in the Islamic world, in particular in the Arab Middle East. He may indeed enjoy higher popularity rates in some Arab capitals than in Ankara.

On the other hand, success may come at a price. Much like the United States and the West, Turkey and the AKP administration have already faced criticism for double standards and duplicity in their foreign policy. The recent uprisings in several Middle Eastern countries highlighted the inability of Turkish foreign policy to stand up to the high expectations raised in Arab public opinion, as well as questioned its commitment to democracy and liberal values. While Arab liberals turned towards Turkey for support, they often found the AKP government dithering between its verbal commitment to democracy and Realpolitik concerns. This underlined that Turkish commitment to liberal democratic values could wane, when major economic and strategic interests were at stake. It was easier for Prime Minister Erdoğan to take a critical - albeit somewhat belated - position of the Mubarak regime in Egypt than in Libya. Egypt and Turkey have been competing for regional influence for years, while there were no significant Turkish economic stakes in Egypt. In contrast to that, Turkey's circumspection regarding the Libyan uprising and its opposition to any sort of international intervention seemed to be correlated with the high level of Turkish investment in the country, as well as an opposition in principle to any sort of Western intervention in the Middle East. Turkey's double standards on Egypt and Libya brought to a similar position with these countries which the AKP administration used to chastise for the questionable moral basis of their foreign policy.

Similarly, Turkey's relations with Sudan, one of the large peripheral states of the Arab Middle East, have also questioned the normative base of Turkish foreign policy during the AKP administration. The Darfur crisis in the west of the country has since 2003 attracted international concern about a humanitarian catastrophe of huge proportions. This led the International Criminal Court (ICC) in 2008 to issue an arrest warrant against the President of Sudan Omar Hassan al-Bashir, due to alleged war crimes and genocide perpetrated under his instructions by the Sudanese army against the civilian population in Darfur. Nevertheless, the sensitivity of the AKP administration on human rights issues seemed to evaporate in this case. 
Turkey has refrained from condemning the acts of President al-Bashir of Darfur and has maintained cordial economic and political relations. In fact, al-Bashir was planning to attend a summit of the Organization of the Islamic Conference in late 2009 in Istanbul. He had to cancel his participation at the last minute due to mounting international criticism against Turkey. What struck the attention of many though however was the defence line by several Turkish politicians against the accusations of the ICC. Prime Minister Erdoğan himself argued that he was comfortable with al-Bashir's visit because 'a Muslim cannot commit genocide' (Özkan and Akgün 2010, 7). This attitude of the AKP government toward al-Bashir and the Darfur crisis cast doubts on the sincerity of the normative base of the approach towards Israel and Iran.

Turkey's stance on the Palestinian and Iranian nuclear questions comprised evidence of Turkey's growing self-confidence, as well as emancipation from Western policies in the Middle East (Grigoriadis 2010b). While these initiatives could be considered part and parcel of a more proactive and constructive regional role, Turkey did not hesitate to markedly differentiate its position from the West on these two key issues. Whereas Turkey would gain the praise of most of the West for its promotion of conflict resolution, regional integration and stability in the Middle East, these two policy initiatives rekindled debates about Turkey's 'shifting axis' and disengagement from its Western strategic anchors (Turan 2010). The shift of Turkey's relations with Israel and Iran has raised eyebrows in the West and led some authors to question Turkey's commitment to the West, as well as the credibility of the liberal pledges of its new foreign policy (Cagaptay 2009; Oğuzlu 2008).

What was less likely though was the concern with which several Arab states met Turkey's increasingly one-sided approach on the Palestinian question. These concerns were not only expressed by countries that had signed peace agreements with Israel such as Egypt and Jordan and could thus be exposed as 'Western stooges' by Turkey's active support for Palestinian militancy and increasing pressure on Israel. Even regimes with impeccable records of resistance against Israel and anti-Americanism came to imply that they would prefer a Turkey which maintains a good working relationship with Israel and could hence act as a mediator in their disputes. This point was lucidly made by the Syrian President Bashar al-Assad during his July 2010 visit to Madrid. He stated

\begin{abstract}
We view the Turkish-Israeli relations from two perspectives ... The first is Turkish role in the peace process which is built on the relationship between Turkey and Israel and the relationship between Turkey and Syria. Any mediator must have good ties with both parties. The second perspective is that the Israeli government's policies are not only the attack on Freedom Flotilla, but its non-response to the indirect SyrianIsraeli talks in Turkey in 2008 and the war on Gaza. ... All of these affected the Israeli-Turkish relations. ... As a result, these relations have not been back to normal and the Turkish role will be difficult to make these talks take place ... Therefore, if Turkey's role in the negotiations process on the Syrian track recedes, this will affect regional stability. (Syrian Arab News Agency (SANA) 2010)
\end{abstract}

Assad's statement was all the more interesting as it originated from a leader of a country considered Israel's archenemy in the region. It highlighted that the state of Turkish-Israel relations concerned all regional actors. Only through a close relationship between the two countries would it be possible for Turkey to play a constructive role in conflict resolution. While the deterioration of Turkey's relations with 
Israel barely made any contribution to regional conflict resolution, it paid dividends in forging Turkey's Middle Eastern identity and reinforced its leadership ambitions within the region. By claiming the mantle of anti-Israeli struggle Turkey became indigenized in the eyes of the 'Arab street' and confirmed its hitherto contested role as a natural insider of Middle Eastern politics.

Turkey's attempt to claim a mediating role between Iran and the West on Iran's nuclear programme has so far produced few tangible results. The problem persists, and no final solution has been achieved on the question of safely enriching Iran's uranium for peaceful purposes. It has, however, underlined the emancipation of Turkey's strategic planning and foreign policy, as well as its ambition for a leading role in the Middle East. Turkey's regional interests have become too important to be compromised by US, European or Israeli concerns regarding Iran and its nuclear ambitions. The endgame of the Iranian nuclear conundrum will provide evidence on whether this reconfiguration was rational or a case of strategic overstretch.

Several statements of key AKP officials including Prime Minister Erdoğan seemed to confirm Turkey's towering ambitions. In a article of his, Erdoğan attempted to reconfigure EU-Turkey relations in view of what has transpired since the start of Turkey's EU accession negotiations in 2005. He argued that

... emerging powers such as Brazil, India, Turkey, and others are playing very assertive roles in global economic affairs. The European Union cannot be the one sphere that is immune to these changes in the balance of power. The financial crisis has laid bare Europe's need for greater dynamism and change: European labour markets and social-security systems are comatose. European economies are stagnant. European societies are near geriatric. Can Europe retain power and credibility in the new world order without addressing these issues? Meanwhile, as a candidate for EU membership, Turkey has been putting its imprint on the global stage with its impressive economic development and political stability. The Turkish economy is Europe's fastest-growing sizable economy and will continue to be so in 2011. According to Organization for Economic Cooperation and Development forecasts, Turkey will be the second-largest economy in Europe by 2050 ... Turkey is bursting with the vigour that the EU so badly needs. And it's not only economics. Turkey is becoming a global and regional player with its soft power ... Turkey has been an active player in all the major areas of global politics and we do not intend to surrender this momentum ... Sometimes I wonder if Turkey's power is an impediment to its accession to the Union ... We are no more a country that would wait at the EU's door like a docile supplicant. Some claim that Turkey has no real alternative to Europe ... However, the opposite is just as valid. Europe has no real alternative to Turkey. Especially in a global order where the balance of power is shifting, the EU needs Turkey to become an ever stronger, richer, more inclusive, and more secure Union. I hope it will not be too late before our European friends discover this fact. (Erdoğan 2011)

Foreign Minister Davutoğlu also stated in a interview that Turkey 'could already set its own strategic axis' (Anatolia News Agency 2010). In view of these, Europe appears to no more carry the heavy symbolic importance which it carried for generations of Ottoman and republican Turkish reformers. This might lead to a serious threat of overestimating Turkish strategic potential in the effort to claim the role of a 'central power'. What Davutoğlu assumes is a Turkey with a fast growing economy, democratizing regime and willingness to spearhead globalization on a regional and global basis. Nonetheless, while Turkey has grown stronger economically and diplomatically under the AKP administration, the risk of overextending Turkish strategic ambitions remains significant. Turkey's strategic links with the West and 
European membership perspectives have been among the underlying factors for Turkey's stellar economic performance and consequent growing international clout. It would be rather foolhardy to engage in an anti-Western rhetoric which might pay dividends in Turkey's domestic political front or in the Arab public opinion but really weaken the long-term strategic potential of Turkey. It is due to the close links between Turkey and the West and the prospective EU membership which help consolidate the democratic regime and support economic growth that the country becomes appealing to its neighbouring states.

\section{The shadow of the 'Arab Spring' - conclusions}

The outbreak of the 'Arab Spring' in January 2011 has shattered many of the assumptions about Middle East politics in the region and beyond. Turkish foreign policy also had to face a hard reality check. As high expectations about Turkey's ability to lead developments in the region were soon dashed, many regional policy pillars came to be disputed. Turkey's special relationship with Syria came to an end, following the outbreak of the Syrian civil war. As Turkey fully supported the opposition forces, all relations with the Assad regime were broken off, and Turkey was increasingly seen as a party to the conflict. This led to a severe deterioration of bilateral relations with Iran, as the latter firmly supported the Assad regime in the Syrian civil war. Improving relations with Iraqi Kurds raised the level of mistrust in the relations between the Turkish and the Iraqi federal government. In Egypt, while the 2011 collapse of the Mubarak regime and the rise of the Muslim Brotherhood to power raised the prospect of a strategic partnership between Egypt and Turkey, the July 2013 military coup in Egypt removed the most friendly towards Turkey government in the Arab world and brought Egyptian-Turkish relations to a low point. In the eyes of many, Turkey ceased to pursue a Middle East policy based on regional cooperation and conflict resolution, but rather on the sectarian affiliations of the parties.

While the 'Arab Spring' has indeed cast a shadow on the capabilities of Turkish foreign policy, it has not questioned the basic findings of this study. The foreign policy vision of the AKP administration may not be as original as some would argue, but fits within a cross-party consensus about Turkey's strategic identity. Turkey's growing regional and global importance has added relevance to this vision; this does not mean, on the other hand, that it has suddenly turned into a global actor (Sanberk 2010, 9). The 'Arab Spring' has proven to be a crucial reality check in that respect. Turkey's growing role in international politics is primarily a function of its successful democratic consolidation and solid economic performance. The latter can be attributed to the dynamism of Turkish entrepreneurship and sound economic policies but remains conditioned on Turkey's economic, political and strategic integration with the West. Turkey's regional appeal is bound to suffer in the long term, if Turkey opts to follow an unaligned 'third-worldist-cumnew-emerging-power' track. In addition, excessive emphasis on the normative basis of Turkish foreign policy is likely to backfire and expose the country to the sort of criticism Turkey itself used to express against other states with a global strategic agenda. By raising the bar of 'principled foreign policy', Turkey runs the rise of falling victim to the same inconsistencies it has accused the Western powers of. Turkey's stance in the 2011 Libyan uprising provided ample evidence for that. 
This is a price that any state moving from the backstage to the front stage of international politics may have to pay.

Whilst Turkey has indeed claimed its autonomy in shaping its strategic agenda, this does not necessarily mean a dichotomy of Western and Turkish strategic aims. Some of the initiatives of Turkish diplomacy have reinforced those views arguing that Turkey would be tempted to the role of an unaligned middle 'supraregional' power (Kardaş 2010, 128). Its partnership with the West would far less predictable under these circumstances (Lesser 2010, 2). This could imply cooperation with other emerging powers, such as Brazil, but also could result in significant risks, which a country like Brazil would not share. Turkey still needs the West more than the West needs Turkey. A shift of Turkey's foreign policy to reflect its rising role in the Middle East could be taken for granted. The success of this reconfiguration, however, depends on the maintenance of its impeccable Western credentials as a full member of NATO and a prospective EU member, besides strengthening its links with the Middle East. While Turkey is indeed gaining regional clout, moving too fast towards de-alignment could cause formidable risks and result in serious turbulences and setbacks (Grigoriadis 2010b, 17). Turkey may rather unpleasantly discover that it is not yet as strong as it thinks. In other words, Turkey may soon experience a severe capability-expectation gap (Kardaş 2010, 130). As the author of the 'Wiki-leaked' US diplomatic cable aptly put, combining 'Rolls Royce ambitions' with 'Rover resources' might not be the wisest way to win a car race (Berlin Office 2010).

\section{Notes}

1. Ottomanism in the late Ottoman era referred to a political movement promoting constitutionalism and a civic Ottoman identity devoid of religious and ethnic connotations.

2. To mention an example highlighting progress achieved, while the first made-in-Turkey car, the 'Anadol', has been a subject of persistent mocking since the 1970s, Turkey has become one the leading exporters of automotive goods toward the European market.

\section{Notes on contributor}

Ioannis N. Grigoriadis is an assistant professor and Jean Monnet Chair of European Studies at the Department of Political Science \& Public Administration, Bilkent University. Between 2004 and 2009 he taught at Sabanci University, Isik University and the University of Athens. His research interests include European, Middle Eastern and energy politics, nationalism and democratization. His recent publications include Instilling Religion in Greek and Turkish Nationalism: A 'Sacred Synthesis', (London and New York: Palgrave Macmillan, 2012), Trials of Europeanization: Turkish Political Culture and the European Union, (London and New York: Palgrave Macmillan, 2009), 'Religious Courses in Turkish Public Education: Explaining Domestic Change with Europeanization Theory', Journal of Church and State (forthcoming) (with Tugba Gurcel), 'Minorities' in Metin Heper and Sabri Sayarı, eds., The Routledge Handbook of Modern Turkey (London and New York: Routledge, 2012), pp. 282-292, 'The Unripe Fruits of Rapprochement: Greek-Turkish Relations in the post-Helsinki Era', International Journal, Vol. 67, No. 1, Winter 2011-2012, pp. 119-133, 'Reform Paradoxes: Academic Freedom and Governance in Greek and Turkish Higher Education', Southeast European and Black Sea Studies, Vol. 12, No. 1, March 2012, pp. 135-152 (with Antonis Kamaras), 'Hubris, Ate and Nemesis: Taking Stock of the Greek Crisis', World Policy Journal, Vol. 28, No. 2, June 2011, pp. 73-82, 'Redefining the Nation: The Shifting Boundaries of the "Other" in Greece and Turkey', Middle Eastern Studies, Vol. 47, No. 1, January-February 2011, pp. 167-182, 'Mutations of Turkish Nationalism: From Ulusalcllik to the Ergenekon Affair', Middle East Policy, Vol. 17, No. 4, Winter 
2010, pp. 101-113 (with Irmak Özer), 'Europe and the Impasse of Centre-Left Politics in Turkey: Lessons from the Greek Experience', Journal of Balkan and Near Eastern Studies, Vol. 12, No. 3, Fall 2010, pp. 259-274 (with Ziya Öniş), 'Friends No More?: The Rise of Anti-American Nationalism in Turkey', Middle East Journal, Vol. 64, No. 1, Winter 2010, pp. 51-66, 'Islam and Democratization in Turkey: Secularism and Trust in a Divided Society', Democratization, Vol. 16, No. 6, December 2009, pp. 1194-1213 and 'The Orthodox Church and Greek-Turkish Relations: Religion as Source of Rivalry or Conciliation?' in Jeffrey Haynes (ed.), Religion and Politics in Europe, the Middle East and North Africa (London: Routledge, 2009), pp. 51-70.

\section{References}

Abramowitz, M., and H.J. Barkey. 2009. Turkey's transformers: The AKP sees big. Foreign Affairs 88, no. 6: 118-28.

Altunışı, M.B. 2008. The possibilities and limits of Turkey's soft power in the Middle East. Insight Turkey 10, no. 2: 41-54.

Altunışı, M.B. 2009. Worldviews and Turkish foreign policy in the Middle East. New Perspectives on Turkey 40: 169-92.

Anatolia News Agency. 2010. Foreign Minister Davutoğlu says Turkey sets its own axis. Today's Zaman, August 5.

Aras, B. 2009a. The Davutoğlu era in Turkish foreign policy. Insight Turkey 11, no. 3: $127-42$.

Aras, B. 2009b. Turkey's rise in the Greater Middle East: Peace-building in the periphery. Journal of Balkan and Near Eastern Studies 11, no. 1: 29-41.

Aras, B., and A. Gorener. 2010. National role conceptions and foreign policy orientation: The ideational bases of the Justice and Development Party's foreign policy activism in the Middle East. Journal of Balkan and Near Eastern Studies 12, no. 1: 73-92.

Aras, B., and R. Karakaya Polat. 2007. Turkey and the Middle East: Frontiers of the new geographic imagination. Australian Journal of International Affairs 61, no. 4: 471-88.

Atl1, A. 2011. Businessmen as diplomats: The role of business associations in Turkey's foreign economic policy. Insight Turkey 13, no. 1: 109-28.

Berlin Office. 2010. Wikileaks files show US worries about Turkish PM's dependability. Hürriyet Daily News, November 29.

Bozkurt, A. 2010. Davutoğlu sees Turkey among top 10 world players by 2023. Today's Zaman, January 5.

Brzezinski, Z. 1997. The grand chessboard: American primacy and its geostrategic imperatives. 1st ed. New York: Basic Books.

Cagaptay, S. October 26, 2009. Is Turkey leaving the West? An Islamist foreign policy puts Ankara at odds with its former allies. Foreign Affairs, online edition. http://shar.es/ BWfRk.

Cem, İ. 1998. Preface. In Turkey and the world 2010-2020: Emergence of a global actor, ed. Y. Başkut, 3-4. İstanbul: DIVAK.

Cem, İ. 2001. Turkey in the new century. 2nd ed., expanded. İstanbul: Rustem.

Cem, İ. 2005. Türkiye, Avrupa, Avrasya [Turkey, Europe, Eurasia]. İstanbul: Bilgi Üniversitesi Yayınları.

Davutoğlu, A. 2001. Stratejik Derinlik: Türkiye'nin Uluslararası Konumu [Strategic depth: Turkey's international position]. İstanbul: Küre.

Davutoğlu, A. 2009. Turkish foreign policy and the EU in 2010. Turkish Policy Quarterly 8, no. 3: 11-7.

Devrim, D., and E. Soler i Lecha. 2010. Turkey's new bold visa diplomacy [Notes Internacionals No. 12]. Barcelona: CIDOB.

Erdoğan, R.T. 2010. The changing balances and the rising importance of Turkey. Lecture delivered at the International Strategic Research Organization (USAK), Ankara. http:// connection.ebscohost.com/c/speeches/48180582/full-text-prime-minister-erdogans-speechusak-changing-balances-rising-importance-turkey

Erdoğan, R.T. 2011. The robust man of Europe. Newsweek, January 17.

Grigoriadis, I.N. 2010a. The Davutoğlu doctrine and Turkish foreign policy [ELIAMEP Working Paper 8]. Athens: ELIAMEP. 
Grigoriadis, I.N. 2010b. Matching ambitions with realities: Turkish foreign policy in the Middle East [ELIAMEP Working Paper 14]. Athens: ELIAMEP.

Grigoriadis, I.N., and A. Kamaras. 2008. Foreign direct investment (FDI) in Turkey: Historical constraints and the AKP success story. Middle Eastern Studies 44, no. 1: 51-66.

Hammed, L. 2011. Iran and Turkey with different aspirations for Shamgen visa. AK News, March 7.

Istanbul Office. 2010. Turkey, Syria, Jordan, Lebanon to set up Economic Partnership Council. Zawya, August 9.

Kalın, İ. 2011. Is Turkey a model for the Arab world? Today's Zaman, February 11.

Kardaş, Ş. 2010. Turkey: Redrawing the Middle East map or building sandcastles? Middle East Policy 17, no. 1: 115-36.

Kirişçi, K. 2009. The transformation of Turkish foreign policy: The rise of the trading state. New Perspectives on Turkey 40, no. 1: 29-57.

Lesser, I.O. 2010. Rethinking Turkish-Western relations: A journey without maps [on Turkey analysis]. Washington, DC: German Marshall Fund of the United States.

Oğuzlu, T. 2008. Middle easternization of Turkey's foreign policy: Does Turkey dissociate from the West? Turkish Studies 9, no. 1: 3-20.

Öniş, Z. 2011. Multiple faces of the 'new' Turkish foreign policy: Underlying dynamics and a critique. Insight Turkey 13, no. 1: 47-65.

Özal, T. 1988. La Turquie en Europe [Turkey in Europe]. Paris: Plon.

Özbudun, E. 2007. Democratization reforms in Turkey, 1993-2004. Turkish Studies 8, no. 2: 179-96.

Özkan, M. 2011. Turkey's rising role in Africa. Turkish Policy Quarterly 9, no. 4: 93-105.

Özkan, M., and B. Akgün. 2010. Why welcome Al Basheer? Contextualizing Turkey's Darfur policy [SETA Policy Brief No. 45]. Ankara: SETA.

Rosecrance, R.N. 1986. The rise of the trading state: Commerce and conquest in the modern world. New York: Basic Books.

Sanberk, Ö. 2010. Transformation of Turkish foreign policy. Istanbul: BILGESAM.

Syrian Arab News Agency (SANA). 2010. President Al-Assad's joint press conference with Premier Zapatero. http://sana.sy/eng/22/2010/07/07/296830.htm.

Turan, I. 2010. Turkish foreign policy: Challenges to Turkey's Western calling. Washington, DC: German Marshall Fund of the United States.

Turkish Grand National Assembly. 2011. The constitution of the republic of Turkey. http:// www.byegm.gov.tr/Content.aspx?s=tcotrot. 